\title{
Institutions and market creation: evidence from the experience of transition countries *
}

\author{
Lionel Artige and Rosella Nicolini
}

This version: September 2013

\begin{abstract}
This paper proposes an empirical analysis for asessing the extent to which multinational firms can effectively support market creation strategies. Our setting focuses on the transition countries, namely ex-socialist countries. Focusing on the lending policy of the European Bank for Reconstruction and Development (EBRD), we build an original database by organizing the public records of the credit contracts signed by the EBRD. Our empirical strategy is able to disentangle that the credit selection that favored the entry of foreign multinational corporations into these countries served as one of the pillars for consolidating their transition to the market economy.
\end{abstract}

Keywords: Investments, Multinational firms, Transition Economies

JEL Classification: F20, F63, P33, P33

${ }^{*}$ Lionel Artige: Department of Economics, HEC - Université de Liège.

Rosella Nicolini (corresponding author): Department of Applied Economics, Universitat Autònoma de Barcelona, Edifici B, Campus UAB, 08193 Bellaterra (Barcelona). Contact: rosella.nicolini@uab.es. Phone +34935814573 . 


\section{Introduction}

The role of institutions and their strategies for triggering economic development are topics that have been widely discussed in the economic literature. In the case of developing countries, it is widely known that foreign direct investment (FDI) is one of the most effective tools for endorsing the development process. The principal limitation to FDI inflows in these countries, however, is market risk which entails serious concerns about profits when settling economic activities in developing countries (Markusen, 2002). Therefore, in this context, the presence of an international institution supporting capital flow entry is often considered an effective deterrent to market risk.

This paper investigates the determinants of capital entry in a selected sample of countries, namely, the ex-socialist countries, as an effective device for endorsing their economic development and the creation of a market system. We define market system as the existence of a competitive interaction among sellers and buyers in the spirit of a competitive economic exchange process. Under this perspective, foreign firms (namely, multinational firms) investing in ex-socialist countries and bringing a competitive culture with them have been expected to be a catalyst for consolidating the market economy during the transition period.

The core of the evidence we discuss in this study consistes of the analysis of the capital flow directed to these countries, intermediated by an international institution: the European Bank for Reconstruction and Development, (EBRD). Our argument is that the EBRD adopted a tailored lending strategy by selecting the FDI option as one of the principal driving forces for the creation of a market system in a risky environment.

Our approach is original and novel: we exploit information about the credit contracts granted by the EBRD to tackle a more general question, namely, the capital entry selection as a strategic tool for development. We adopt a two-step strategy. First, we create an original database by organizing the public information on these credit contracts. The contracts include loans and other types of financing tools that the EBRD granted to firms to perform investment projects in one or more ex-socialist countries. ${ }^{1}$ Then, focusing on these credit contracts, we are able to control for part of the features that favor the entry of foreign entrepreneurs in transition countries. Finally, we empirically test the association between the credit selection toward international investors (namely, multinational entreprises - MNEs-) and the consolidation of the market system during the transition process.

The micro-data we examine and the historical period we focus on help to define a simple identification strategy.

\footnotetext{
${ }^{1}$ The EBRD very often just partially financed these projects.
} 
The rationale for our strategy is straightforward: the EBRD lending policy is expected to match projects and country needs. At the right time, the EBRD finances the appropiate projects that are expected to help create a competitive market system in each host destination. In this respect, we investigate the exent to which MNEs could have a specific role in the EBRD's development strategy by looking at the potential determinants affecting the size of the EBRD credit contracts granted to them. ${ }^{2}$

A brief discussion of the EBRD's history, policy and mission is useful here.

The EBRD was created in 1991 just after the Soviet Bloc had collapsed. Since then, its purpose has been assisting the countries of that region in transforming their centrally planned economic systems into market-oriented economies. Its mandate involves promoting private aid and entrepreneurial initiatives including de-monopolization and privatization (Besley et al. 2010).

Owned by sixty-one countries and two intergovernmental institutions, the European Union and the European Investment Bank with a capital of 20 billion euros, the EBRD fits the definition of an international financial institution (IFI) given by the Organization for Economic Co-operatoin and Development (OECD, 2013). Regarding IFIs, the OECD intends that public financial institutions play an important role in improving credit accessibility (particularly, for small and medium entreprises, SMEs) in developing countries. Contrary to national development banks, an IFI is expected to provide credits when the private sector lags behind because of difficult market conditions or political pressure (OECD, 2013). ${ }^{3}$ Unlike private investment banks, the EBRD has sovereign shareholders that do not receive dividends. This feature, together with its stable sovereign ownership, allows the EBRD to raise funds under the best conditions and to simultaneously face the high risks inherent in investing in the region.

When the EBRD started its lending operations in 1991, the business environments of all of ex-socialist countries were characterized by large reductions in output, the complete disorganization of production, macroeconomic and political instability, and inadequate banking sectors (Vuylsteke, 1995). Beside certain countries were far from being fully fledged democracies. The EBRD was presented as the ideal financial partner to grant credits in a high risk enviroment with special attention to either native or foreign private entrepreneurs. ${ }^{4}$

\footnotetext{
${ }^{2}$ In Damijan et al. (2013), the authors emphasize that FDI in transition countries primarly did not aim at entering the biggest markets or take over (in the case of mergers and acquisitions) the most efficient firms. If so, another reasonable scope needs to be clarified.

${ }^{3}$ These institutions focus mostly on SME programmes and favor local firms to have access to the international trade system. IFIs are expected to intensify their credit activity when credit risk is high (and banks have lower incentives to lend) or a country is passing through a recession period.

${ }^{4}$ According to our estimations, the share of public clients between 1991 and 2003 was about $12.5 \%$ of the total cumulated investment.
} 
Attracting foreign private entrepreneurs in risky host countries is not an easy task, but despite other experiences, the FDI entry process in former socialist countries could count on a key player (i.e the EBRD) that de facto is able to control and drive the foreign investment flows according to specific institutional priorities (Bevan and Estrin, 2004). In this sense, the development process of former socialist countries at the beginning of their transition process may not be fully assimilated to a random or uncontrolled one. Relying on the information disclosed by credit contracts granted by the EBRD to local and foreign entrepreneurs, our goal is to depict how and which FDI inflows were prioritized by the EBRD to support the economic transition to recipient countries.

At the beginning of the EBRD's activity, the country risk (in host markets) was high because of the macroeconomic turmoil. All potential borrowers lacked market experience and had no history of creditworthiness. Further, the credit-granting decisions made by the EBRD were not affected by competition because local banks were insolvent and foreign banks did not enter these risky markets in the early transition period (Lanine and Vander Vennet, 2007). Inside the transition landscape, as with any economic agent, the objective of the bank is to maximize profits from investment projects by using all the instruments available in the financial markets to raise funds and protect its portfolio against risks. ${ }^{5}$

Because of its institutional mission, the EBRD also operates with another priority: to foster entrepreneurial activities in the most effective ways. However, the returns to support investments carried out by local or international firms (MNEs) may not be always identical. In a recent paper, García- Santana (2012) discusses the effectiveness of relying on MNEs to establish a market system in developing countries. This result stems from the lack of financial frictions for MNE branches when undertaking FDI in developing countries. His argument is quite intuitive: the real effectiveness of MNE investments triggering the creation of a competitive market in the host countries hinges the possibility that MNEs finance themselves their own projects and do not address their credit demand to the local credit market. In this sense, in former socialist countries, the goal of supporting the transition process to the market economies can be achieved by adopting a preferential strategy for privileging the investments of international corporations rather than those of native firms.

The rationale of pushing economic development through MNE entry is widely discussed in Burstein and Monge-Naranjo (2009) and McGrattan and Prescott (2007). Lowering barriers to foreign firms that bring technological advantages to the host economies yields a substantial

\footnotetext{
${ }^{5}$ In fact, the conditions under which the EBRD operates are not totally identical to those of other investment banks. The EBRD aims at being a catalyst for financial institutions and wants to avoid crowding them out. In other words, the EBRD does not see other financial institutions as competitors (EBRD, 1999).
} 
increase in welfare in those territories (Damijan et al., 2013). It has been proven that this action can be undertaken successfully by MNE, because having easy access to the international financial market means that they can borrow abroad and thus operate at their optimal size in the host markets (García Santana, 2012). A clear example of this practice in developing countries is the empirical analysis proposed by Dang (2013) for Vietnam. In the case of Vietnam, the author shows that FDI is able to not only consolidate the market system, but also improve the quality of local institutions. This framework does not fully apply to the case of financing investments in transition countries. In the historical period referenced in this study, even MNEs did not have full access to the open international credit market when considering that investments in transition countries would have been interesting. The EBRD has always represented the key lender. In light of the theories discussed above, one would expect that the EBRD's strategy would be to relax requirements in order to grant credit contracts to the MNEs while being more strict with the native firms. ${ }^{6}$

By exploiting the information disclosed by the (granted) credit contracts, we plan an econometric strategy to identify similarities and differences in the lending policy of the bank conditional on the type of client. Then, we aim at establishing whether the EBRD lending policy really privileged the entry of the MNE at the beginning rather than at the end of the transition period. This result would support the hypothesis that the MNE presence was considered one of the pillars for consolidating the market system.

In developing our analysis, we proceed as follows. In the section that follows, we provide a wide statistical description of the EBRD-client relationship, relying on the content of our database. In Section 3 we introduce our empirical strategy and perform our econometric exercise, and finally, Section 4 concludes and discusses our results.

\section{The EBRD-client relationship}

Our analysis focuses on the very beginning of the transition process. We concentrate on all the credit contracts granted by the EBRD from 1991 to $2003 .^{7}$ In this way, we are able to track the activity of the bank during the period in which it was acting as monopolist-credit-granter in this geographical area. This approach will make it easier to define an identification strategy

\footnotetext{
${ }^{6}$ To a certain extent, the institutional role of the EBRD is expected to adjust the imperfection of an incomplete market.

${ }^{7}$ Limiting our analysis to this period allows us to focus of the intial transition time when the principal purpose was expected to be the creation of a market economy. The period was characterized by an important privatization process. The strategy of analysis we are proposing would not hold if we extended our time span to after 2003 when several oligarchs became important economic agents in various ex-socialist countries.
} 
to test our working hypothesis.

When considering a potential client for a lending contract, the EBRD follows a standard procedure (Vuylsteke, 1995). The bank and its client agree to sign the contract; then, the bank finances the firm, which makes the investment and pays back the loan (plus interest) to the bank. $^{8}$

For the purposes of this study, we built an original database from public data released by the EBRD over time. ${ }^{9}$ Our database includes 1,788 financial contracts signed by the bank with private and public clients from 1991 to 2003. It contains information in each case on the identity and nationality of the clients, the amount of the contract in ECU/€, the value of the investment project, the sector of investment, the year the contract was signed, the type of contract (loan, share, equity, or guarantee), and other characteristics (old clients, private/public, macro-programs, etc). ${ }^{10}$ About $10 \%$ of the contracts in the database have been signed by an MNE as a unique borrower. ${ }^{11}$ In this section, we present a brief overview of the content of our database and discuss the most relevant descriptive statistics.

\subsection{The contracts}

The number of contracts and the amount of annual investments were very low at the beginning of the transition process (see Figures 1 and 2). The EBRD was underusing its capital, and this underuse was a source of criticism among the shareholders and commentators. The underuse was principally due to the severe macroeconomic downturn that affected the entire region. After these initial difficulties, the bank's aim was to strongly increase the portfolio volume. The economic recovery of most of the countries in the region helped the EBRD to sign more contracts and to

\footnotetext{
${ }^{8}$ In this section, for the sake of simplicity, we intend the term "loan" to mean any kind of credit contract the bank may propose.

${ }^{9}$ We need to clarify an important disclaimer about data at hand. Our database has been built by compiling open-access public data. In public records, information about sensitive features at the firm level is extremely limited or missing. Furthermore, we have no sufficient elements to track our sample of firms beyond the time we are considering and match our data with other databases to control for firm performance. Despite these limitations, the data at hand turn out to be sufficient to tackle the question we are interested in, and they may also represent the backbone for potential further developments in the future.

${ }^{10}$ The codification of each entry of this database follows an ad hoc criterion driven by the necessity to organize the public information to which we have access across time. Unfortunately, we are not able to identify each contract with canonical identification numbers (as a VAT number, for instance) of credit recipients. Therefore, fully merging this database with other firm-level databases to complement the missing information is not possible.

${ }^{11}$ Several contracts have been signed by a consortium of firms, and they sometimes involve the presence of a foreign partner. However, tracking the quota of participation of the MNE in the consortium as well as qualifying its participation to the management of the investment is not always possible. Therefore, in these cases, we prefer to include this group of clients with the group of local firms.
} 


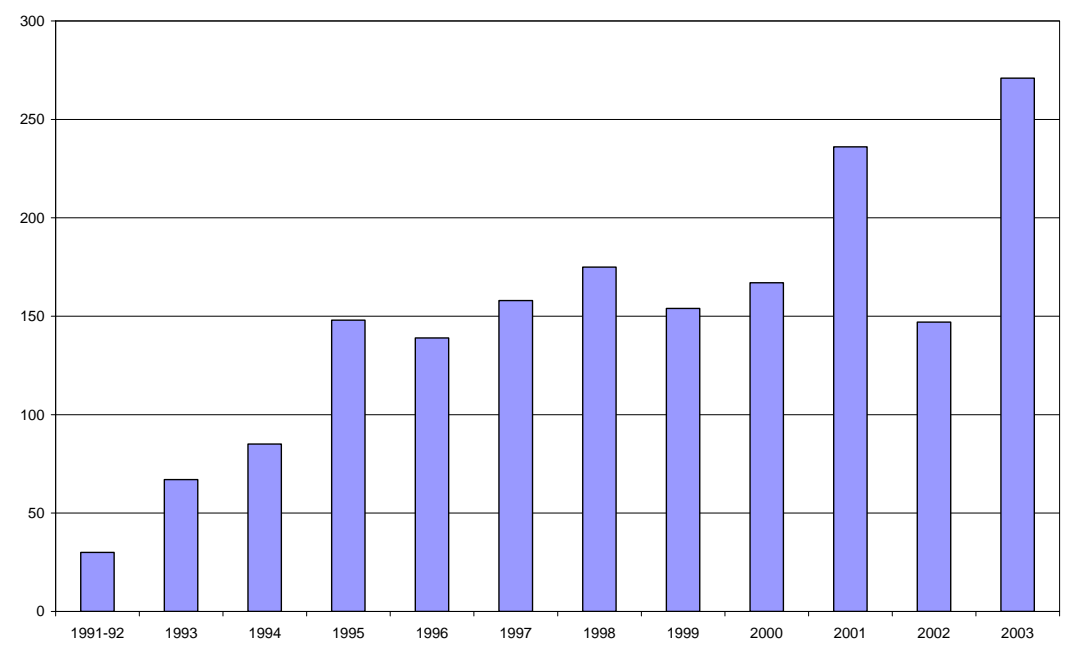

Figure 1: Number of contracts signed by the EBRD between 1991 and 2003.

make sizeable profits from 1999 onward.

According to the information released by the EBRD, the bank designed different kinds of contracts. These contracts all represent the financial instruments by which the bank participates in the realization of the investment project proposed by the borrower. These contracts differ not only in the maturity of the credits but also in other characteristics, which we will discuss below. First, in Table 1, we provide a general overview of the different kinds of contracts signed by the bank, as well as the frequency of the contracts.

[Table 1 about here]

Three (out of thirteen) main categories of credit instruments can be distinguished: loan, share and equity, and guarantee contracts. The loan was the financial contract most frequently used by the EBRD between 1991 and 2003 (Table 1). A loan is generally considered a short-term contract, lasting five years on average and tailored to meet the particular requirements of the project. The credit risk is usually taken by the bank or partially syndicated to the market. A loan may be securitized by a borrower's asset or converted into shares (or both) or may be equity linked. The second important category includes share and equity contracts. Share contracts were signed primarly at the beginning of the EBRD's activity, whereas equity contracts represent a broader category of financial contracts that include share contracts too. An equity investment can be undertaken in various forms, including subscription to ordinary shares. When the EBRD takes an equity stake, it expects an appropriate return on its investment. The bank usually sells its equity investment on a nonrecourse basis, has a clear exit strategy, and takes only a 


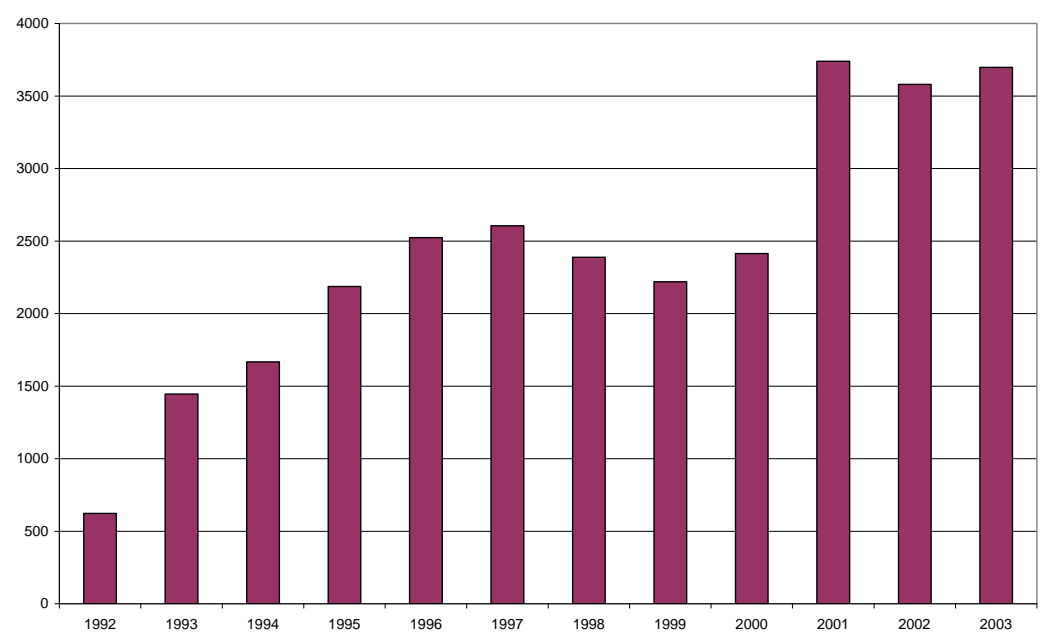

Figure 2: EBRD investments by year (ECU/€ million).

minority position. ${ }^{12}$ The third category of credit instruments refers to guarantee contracts which were used mainly at the end of our dataset period. Through this type of contract, the bank helps borrowers to gain access to financial sources through the provision of guarantees (EBRD, 1999). ${ }^{13}$

Tables 2 and 3 show descriptive statistics on the total values of projects that were selected by the EBRD and the share that it effectively financed. In most accepted projects, the EBRD was not the only lending source. ${ }^{14}$ Statistical information is given for the total population and for two periods, one at the outset of the transition (1993-1995) and the other at the end of the sample period (2000-2003). The total project value of loans was always higher than that of shares, but both decreased over time. The median bank lending in loan contracts remained unchanged over time, whereas it declined in share contracts. This fraction increased proportionally with the total project value, ${ }^{15}$ but the increase was more pronounced for shares than for loans. As a shareholder, the bank can control the management of the firm, which implies a reduction in uncertainty associated with imperfect information about the firm's behavior. The bank tends to

\footnotetext{
${ }^{12}$ Equity is considered to be a noncontingent contract.

${ }^{13}$ According to the OECD (2013), the diffusion of guarantee contracts in developing countries is a device to reduce the financial constraints for SMEs and start-ups. This type of contract represents a positive signal from the SMEs to the market and may entail the starting of a long-term lending relationship between those firms and other private lenders.

${ }^{14}$ The contracts issued by the EBRD always require a cofinanced part which may be through cash financing from the firm or, in other cases, from a consortium of commercial banks. However, the involvement of commercial banks in the credit process is strictly subject to EBRD participation. Hence, even in this case, the EBRD plays the role of dominant credit agent.

${ }^{15}$ The correlation of these two variables is around 0.67 .
} 
augment its participation with the size of the project value in share contracts in order to protect itself against risk. As for loans, the collateral allows for a control of risk.

[Table 2 about here]

[Table 3 about here]

\subsection{Countries and sectors}

Two criteria can account for the geographical distribution of contracts between 1991 and 2003: market size (population size or income per capita) and political regime. Figure 3 shows the geographical distribution of EBRD investments in cumulated terms per capita by country. The Central European countries, which are the most developed countries of the population and which led the transition process, received the largest per capita financing (around 300,000 euros for Slovenia, Croatia, and Estonia), while the Central Asian countries lag behind significantly. The Central Asian countries have not only a poor business climate but also non-democratic institutions. We perform other statistical analysis to obtain more evidence. We split the distribution into three subperiods (1991-1995, 1996-1999, and 2000-2003). Table 4 shows that at the beginning of the transition process, almost half of the investments went to the early starters, in the Central European and Baltic states. Their share later reduced to roughly one-third of the total because it is very likely that in these destinations, the transition process to a market system was quickly established. During the transition process, Russia received an increasing proportion of EBRD investment and its share remained stable. Southeastern Europe saw a progressive increase in its share of EBRD investment during this period. The relative share in Eastern Europe and the Caucasus decreased. Finally, Central Asian countries reached a noticeable share between 1996 and 1999, which fell by half during the final period.

[Table 4 about here]

[Table 5 about here]

As for the distribution by sector (Table 5$),{ }^{16}$ at the beginning of the transition, most of EBRD financing went to the Finance, Telecom, and Oil/Gas/Natural Resources sectors. ${ }^{17}$ Again, with

\footnotetext{
${ }^{16}$ A complete list of all the sectors is included in Appendix A.

${ }^{17}$ In this respect, it is worth noting that private foreign banks entered transition countries to replace the general mono-bank (active during the socialist system) with the purpose of reinforcing the transition and creating a solid banking system (Roland, 2000). More evidence about the EBRD's role in supporting the transformation of the local banking system is widely discussed in Fang et al. (2011). The EBRD also took a limited stake in a few banks during the early stage of the privatization. Although this aspect of the transition period is certainly important, this analysis goes beyond the scope of this study.
} 


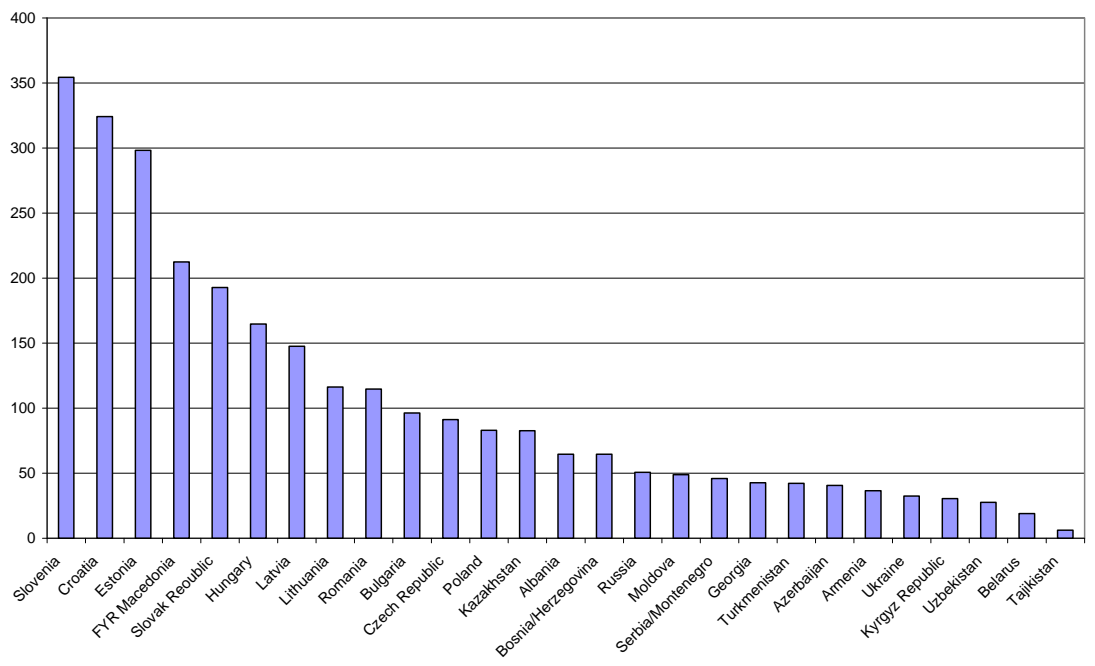

Figure 3: Cumulated EBRD investments per capita by country ( $€$ thousands).

the priority to create a market system, in the first period of the transition, the objectives were to finance infrastructure and to restructure the banking and manufacturing sectors. Thereafter, in the second stage of the development process, the focus of the bank switched to financing the creation of small and medium-sized enterprises.

Our principal working hypothesis is that the MNEs have been strategically selected by the EBRD to support the transition process to a market system, above all at the very beginning when only a few enterprises were active in the host markets. Nevertheless, one could also argue that the strategic choice of supporting MNE projects can simply be driven by the evidence that the types of projects MNEs carry out in transition countries concentrated in less risky (or variable) sectors. This is not the case, however, as supported by the pertinent statistics in Table 6. Considering our whole sample and selecting the sectors accounting for at least $5 \%$ of the overall projects financed by the EBRD, it turns out that the percentage of financed projects (by sector) are identical for both the MNEs and the local firms. Furthermore, these percentages do not vary a lot for the two most important sectors (bank and finance). Again, the data confirm that once the bank planned the strategy to create a market system, all of its lending policy served that purpose.

[Table 6 about here]

\section{Empirical strategy}

The EBRD's strategy combines both its concern about financing feasible projects that have positive economic returns in the host market with its expectation that the credit would be paid 


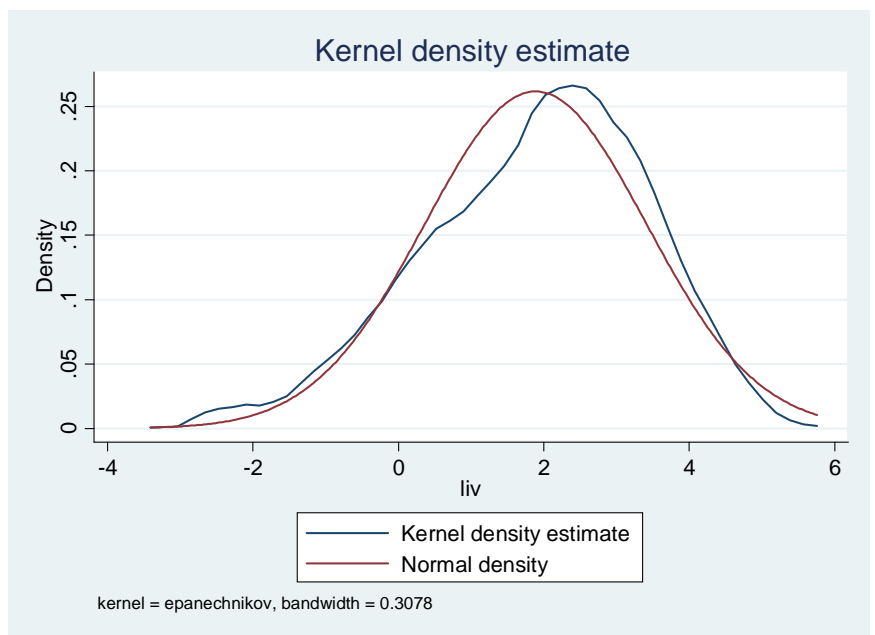

Figure 4: Distribution of value of credit contracts (in logarithm).

back by the borrower in due course. Our empirical exercise builds on these two assumptions, and we aim to clarify the potential differences in credit granting strategies when investment projects are implemented by local or international firms.

Before proceeding with the analysis, the relationship between the value of the contract and the value of the investment project deserves some comments. Taking the logarithm of the value of the credit (LIV) and the logarithm of the ratio between the value of the credit and the value of the investment project (LQ_IV), one can easily detect that no direct proportionality exists between the value of the investment and the part financed by the EBRD. Figures 4 and 5 represent the two kernel estimations of the previous variables.

The value of the credit is definitely a one-pick distribution, whereas the share is a two-pick one. Therefore, the value of the credit granted by the EBRD is not just a function of the value of a project, but also a combination of several other factors. The scope of our empirical strategy is to learn more and clarify these further determinants under an economic development perspective.

\subsection{Econometric specification}

In order to run our econometric exercise, we match data referring to a few characteristics of the contracts signed by the bank with other data referring to the environment in which the investment project was run. The principal difficulty is identifying the proper indicators to run the estimations according to the data at hand. To that end, we refer to the current findings in the economic literature.

To identify the local economic environment in which investors were expected to operate in 


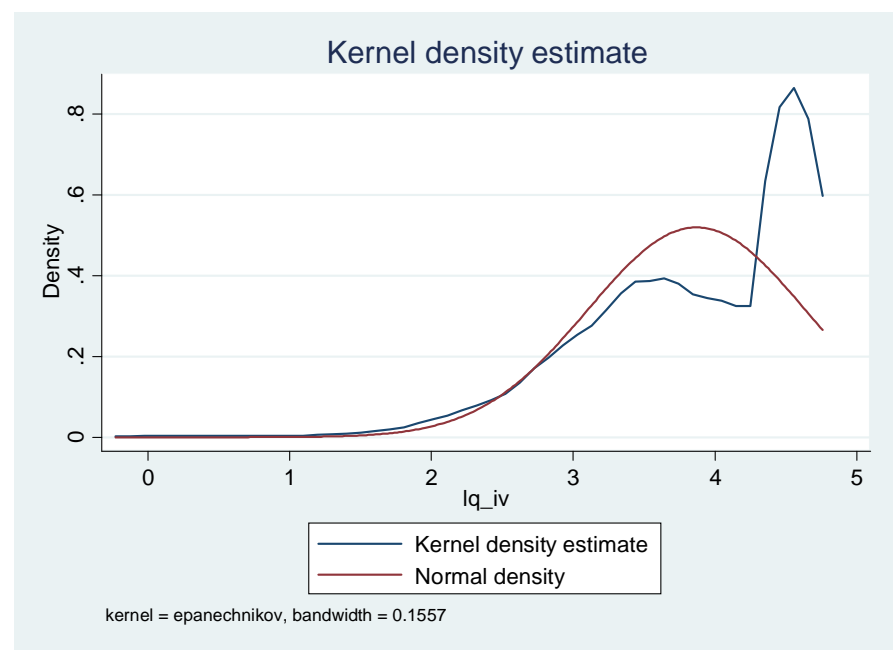

Figure 5: Distribution of the share of EBRD's financing (in logarithm).

host countries, we consider four different indicators that aim at capturing the most relevant factors affecting business activity: type of regime, purchasing capacity of local citizens, degree of trade liberalization, and advances in the privatization process as an indicator of the market system consolidation process.

The level of local wealth, as an index of the purchasing capacity of the local population, is represented by the value of year GDP per capita (in $\$$ ). The measure of the level of development of democratic institutions is taken from the Polity IV project. This is a coded index for the level of democracy (DEM) of independent states. This index varies between minus ten (for an absolute autocracy) and plus ten (for a fully fledged democracy). It is obtained by combining the evaluation of different elements (for instance, the independence of the executive authority, openness of the executive recruitment, regulation of the chief recruitment process, and individual participation in the election system, among the others) that allow for determining the quality of a regime's democracy. ${ }^{18}$

Specific features of the transition process are embedded in three indicators developed by the EBRD: governance and enterprise restructuring (GOV), large and small scale privatization (SB_P), and trade and foreign exchange system liberalization (FOREX).

The annual values of the GOV indicator (ranging from 1 to 4 as a continuous variable) are determined by taking into account the financial discipline at the enterprise level, the credit and subsidy policies for business activities, and the degree of effective corporate control exercised through the financial institutions. The SB_P indicator (again, a continuous variable larger

\footnotetext{
${ }^{18}$ Refer to the Polity IV website for details on how the scores are computed: www.systemicpeace.org/polity/polity4.htm.
} 
than 1) tracks the degree of the privatization process, referring to information on the no-state ownership of small enterprises, the effective tractability of the land, and the diffusion of private ownership that aims at achieving the same type of performance as in advanced countries. Finally, the FOREX index (a continuous variable larger than 1) embeds the degree of free import/export regime, the current account convertibility, the removal of the tariff barriers, and eventually the accession to the World Trade Organization (WTO). Although these indexes are determined via qualitative assessments, the previous indicators (namely, GOV, SB_P, FOREX and DEM) are not strongly correlated. There is a low and positive but statistically significant correlation among them (when for statistical reasons all variables are considered in logarithm, refer to Table 7). The unique weak negative correlation is between the democracy and privatization process: a reasonable assumption is that established democracies usually do not run large, important privatization programs.

In addition to the variables controlling for the local environment of investors, we also introduce some proxies for controlling some specific features of the investors that are enjoying the credit granted by the EBRD. In line with the current literature, the size of the loan (IV) can be interpreted as a evidence borrower quality. In an empirical test, Boot et al. (1991) establish that larger loans, as well as loans with a longer maturity are more likely to have a lower level of collateral. The type of contracts signed by the bank and the type of clients also reveal important information. A bank can usually discriminate between clients by proposing different contracts to them. Although these contracts can be grouped by type, each is often tailored to the client's needs. Looking at the most widespread class of contracts, Inderst and Mueller (2006) conclude that debt contracts are optimal when the lender is conservative, whereas equity contracts are optimal when the lender is aggressive. For instance, investments by small firms in tangible assets such as equipment or property are expected to be financed by debts.

Our empirical strategy owes much to the previous contributions. The maturity of a credit contract is different for each category of contract, and the type of contract is an approximate indicator of this credit maturity, as mentioned above. We thus consider that the amount of the credit contract is supposed to be the result of a combination of market conditions and expected return on investment.

In addition to the value of the credit (IV) granted by the EBRD to the firm, we also take into account features such as the type of the contract, the year it was signed, and the return on investment. The latter can be approximated, for a solvent firm, by the value of its productive investment (namely, logarithm data labeled LIP in the database). This investment value is the minimum level of return of any successful productive investment by the firm, which corresponds to its capacity for repayment. By adopting this hypothesis, we are following and extending 
the results achieved by Holmström (1999), who proved that the investment decision and the distinguishing characteristics of this investment represent a way to disclose the unknown characteristics of an agent. Finally, since other potential importantly features of each client (for instance, the risk evaluation of the clients, the type of collateral associated with each contract) are unavailable, we can control only for the identity of the client by being able to discriminate between a private or public (Public) client. ${ }^{19}$ Finally, we also introduce firm or contract fixed effects to control for the omitted variables for each signed contract. A description of the variables is given in Box 1.

[Box 1 about here]

Our empirical strategy consists of running two different estimation exercises in order to identify the discriminating financing strategy that favors MNE financing over the one for local enterprises (if any) as a device for supporting the market creation system. To this end, we first regress the credits granted to the two groups of firms against the same group of control variables. In this way, we aim at assessing that the conditions yielding the credit granting to MNE are different from the ones for local enterprises.

We formulate our first empirical model as follows. In order to control for the very high variance of observation in our sample, and to ensure the conditions for significant estimations, we take all of our variables in logarithm. Let us define the dependent variable (value of the credit) as $Y(L I V)$. The amount of the credit for financing an investment project is defined as $L I V_{i t j s}$, with $i=$ firm, $t=$ year, $j=$ host country, and $s=$ sector. We consider a group of independent variables to be associated with the contacts (i.e., LIP and Public) and the general market conditions in the host country (i.e., LDEM, LGDP, LFOREX, LGOV and LSB_P). We also include an interaction term $\left(D E M_{j t} * y_{e a r_{t}}\right)$ between the democracy index and the time dummies. This term is meant to track possible changes in the variable democracy over time in each country. Therefore, the equation we consider can be defined as follows:

$$
\begin{aligned}
L I V_{i t j s}= & \alpha_{0}+\beta_{1} L I P_{i t j s}+\beta_{2} P U B L I C_{i}+\beta_{3} L D E M_{j t}+\beta_{4} L G O V_{j t}+\beta_{5} L G D P_{j t}+(1) \\
& +\beta_{6} L F O R E X_{j t}+\beta_{7} L S B_{-} P_{j t}+\beta_{8}\left(D E M_{j t} * \text { year }_{t}\right)+\varepsilon_{i t j s} .
\end{aligned}
$$

Our database is not a true panel but rather a pooling of independent cross sections over time. Hence, we need to control for heterogeneity problems. As argued in Wooldridge (2006),

\footnotetext{
${ }^{19}$ In the case of MNEs being a Public client means being a foreign-state-owned-enterprise (usually managing a public service such as transport activities of public facilities) that invests in a transition country. The identification of Public is then applied to the identity of the credit applicant irrespective of the type of the investment it is planning to carry out.
} 
this pooled structure implies that the dependent variable may have different distributions in different time periods; to control for this, we need to introduce some time fixed effects $\left(\mu_{t}\right)$. The same reasoning applies to the sector dimension, for which we include some sector fixed effects $\left(\mu_{s}\right)$. In addition, as shown, for instance, in Baltagi (2008), we also need to include the unobservable time-invariant individual-specific effect $\left(\mu_{i}\right)$ to control for the heterogeneity problem as much as possible. Controlling for all of these effects allows us to decompose the error term $\left(\varepsilon_{i t j s}\right)$ in the following way:

$$
\varepsilon_{i t j s}=\mu_{i}+\mu_{t}+\mu_{s}+\nu_{i t j s}
$$

where $\mu_{i}$ is the unobservable time-invariant individual-specific effect, $\mu_{t}$ the time fixed effects, $\mu_{s}$ the sector fixed effects, and $\nu_{i t j s}$ denotes the remaining disturbances, which are now expected to be $\operatorname{IID}\left(0, \sigma_{\nu}^{2}\right)$.

The choice of the variable $\mu_{i}$ turns out to be crucial for obtaining independence between the residuals and the dependent variable. In our estimations, we are alternating firm and contract fixed effects, and we will also control for firm or contract clustering errors. The contract type is in fact time invariant according to EBRD statements. In running this first exercise, we expect to get different results when applying the same model to our different subsamples. In particular, in light of the theory discussed by García-Santana (2012), it is also likely that all other regressors will lose part of their statistical significance in the case of MNEs, with respect to the amount of credit the EBRD would grant MNEs on the basis of their reputation, projects, or sectors of activity.

[Table 8 about here]

Table 8 provides descriptive statistics for some of these variables for the overall period and for two specific years: 1993 and 2003. ${ }^{20}$ The dependent variable is the financing amount $(I V)$ granted by the EBRD. This is one of the variables in the bank's profit function, which depends negatively on the riskiness of the project. ${ }^{21}$ This reflects both the screening process and the incentive mechanism that takes place between clients. In our population, this index declines over time because the EBRD financed democracies in Central and Eastern Europe at the beginning of the transition and later started to finance autocratic countries in Central Asia.

The second exercise builds on the results of the first one and aims at tackling a simple question: is the potential discrimination of clients by native and MNE truly a device to sustain

\footnotetext{
${ }^{20}$ We prefer to discuss this evidence by referring to the original data (namely, without the logarithm transformation) to provide a realistic discussion of the available information.

${ }^{21}$ See Stiglitz and Weiss (1981) on credit rationing.
} 
the creation of the market system? If this were the case, the selection of MNE projects is expected to be more intense at the beginning of the transition period (when the democratic process is not fully consolidated) with a reduction in intensity over time.

In order to test this hypothesis, we run the following estimation:

$$
\begin{aligned}
L I V_{i t j s}= & \alpha_{0}+\beta_{1} L D E M_{j t}+\beta_{2} M N E_{i}+\beta_{3} L D E M_{j t} * M N E_{i}+\beta_{4} \text { dloan }_{\text {itjs }}+ \\
& +\beta_{5} \text { dloan }_{i t j s} * M N E_{i}+\beta_{6} L G O V_{j t}+\beta_{7} L F O R E X_{j t}+\beta_{8} L S B \_P_{j t}+\varepsilon_{i t j s}
\end{aligned}
$$

In the previous equation, we gather a selected number of variables that focus on the importance of some institutional variables on the size of the granted credits. First, we introduce $L D E M_{j t}$, which tracks the consolidation of a democratic system in the host economies. As usual, $L G O V_{j t}, L F O R E X_{j t}$ and $L S B_{-} P_{j t}$ are expected to capture the most salient features of the business environment in the host markets. Furthermore, we introduce a dummy for selecting the credits granted to $M N E_{i}$, and the key variable of this exercise is the interaction term between the two previous variables $\left(L D E M_{j t} * M N E_{i}\right)$. If our hypothesis were true (namely, MNEs are an important device for consolidating the market system in the host countries), the coefficient $\beta_{3}$ is expected to be negative and statistically significant, meaning that the size of the credit granted to MNEs is important at the beginning of the transition period. As soon as countries are able to consolidate the democratic regimes, the size of the credits granted to MNEs is expected to reduce. The remaining variables capture the importance of tailoring the granted credit to the type of clients. According to the OECD (2013), loan contracts are most extensively used when clients are able to provide the proper collateral and allow the bank to share the lower degree of risk. Here, we consider that MNEs as international investors have the financial capacity to provide sufficient collateral to the bank. Hence, we introduce the dummy dloan $n_{i t j s}$ to select the credit contracts granted as a loan, and the interaction term $d l o a n_{i t j s} * M N E_{i}$ to track how extensively these contracts are exploited in the case of MNEs. As in the first exercise, we introduce time and sector fixed effects as well as the interaction terms $\left(D E M_{j t} * y_{e a r}\right)$. Finally, we control the heteroskedasticity problem with either the White or the cluster (by contract) correction of errors.

\subsection{Results}

We begin by focusing on the estimation of (1).

First, we concentrate on the full sample, and then we divide it into two groups: local firms and MNEs. We proceed first by assessing whether the fixed effect model should be preferred to the pooled ordinary least square (OLS) model (with the F-test) by selecting the most efficient 
estimation strategy, determined by choosing between contract or firm fixed effects. In all of the regressions, we control for heteroskedasticity by applying either the White or the cluster correction. $^{22}$

\subsubsection{The full sample}

To begin we first consider all contracts in order to identify the main factors that can influence the selection of credit granted by the EBRD. Table 9 shows the output of the OLS estimations for the pool of observations when considering the year and sector dummies and an interaction term $\left(D E M^{*}\right.$ years $)$, which takes into account the transition of the political regime in the host countries toward democracy. In order to control for heteroskedasticity problems, we correct the residuals with either the White or the cluster method. The cluster method is appropriate, since it allows us to take into consideration the fact that one firm can apply for more than one contract. As one might expect, the adoption of fixed effects in the estimation of the full sample turns out to always be extremely significant in the case of contract fixed effects but not firm fixed effects. It is likely that the type of contract signed by the client is somewhat the result of the bank's screening process, and that is automatically defined by the contractual condition a firm is required to fulfill. It is also worth noting that the cluster error correction strategy improves the quality of the estimation. The importance of adopting the cluster error correction strategy stresses that there exist some latent components across the contracts that we need to take into consideration and possibly disentangle.

The results we obtain are robust overall (Tables 9 and 10). The proxies of the repayment capacity (LIP) and the GDP per capita of the host country (i.e., the level of local income) have a positive impact on the amount of credit, confirming the existence of a potential market for business in these countries. Being a public borrower also has a positive impact (when the coefficient is statistically significant) on the amount of credit, which can be interpreted as a guarantee for being a solvent client. By contrast, the group of variables representing the business environment ( $L G O V, L F O R E X$ and $\left.L S B_{-} P\right)$ in the host country are basically not statistically significant, with a few exceptions where they display a negative coefficient: the lack of sufficient established market conditions hampers the investment activity. Instead, the LDEM index seems to have a more significant impact on investment attractiveness, and even its coefficient is sensitive to the type of correction (i.e., contract or firm fixed effects) we are adopting. The negative sign associated with the democracy index indicates that the EBRD increasingly invests in less democratic countries over time (see Subsection 2.2). This can be explained by the fact that at the beginning of the transition, what little credit the EBRD granted was mostly to more

\footnotetext{
${ }^{22}$ The econometric estimations were computed with the Stata 11 package.
} 
democratic countries. It then increased its supply of credit to all types of regimes, and finally increased its investment in less democratic countries as more democratic countries started to be financed by private investment banks. A positive and strongly significant coefficient associated with the existence of a democratic regime in the country hosting the investments should confirm that the strength of a property rights system is an interesting incentive for granting credit.

[Table 9 about here]

[Table 10 about here]

Having considered the full sample, we now divide the sample into two subsamples in order to verify the robustness of our results. The first subsample includes only local firms, and the second is composed of MNEs.

\subsubsection{Local firms}

The result of the F-test shows that the fixed effect model (by contract) should be preferred to the pooled model (Table 11). Instead, the firm-individual fixed effects perform very poorly. Our estimate with contract fixed effects suggests that almost one-third of the variation in the amount of financing is related to the different types of contract (Baltagi, 2008; Baum, 2006). In line with the interpretation provided above and the findings from the theoretical literature, we should expect the EBRD to face a higher risk when financing the projects of independent native firms in host markets at the beginning of their activities. Therefore, the choice of a specific group of contracts rather than others has to be considered a strategy to protect itself against that risk.

As for the significance of the coefficient, the value of the investment project (which we interpret as a measure of the firm's repayment capacity) is always highly significant. The public identity of a client turns out to be important because a public client may be considered by the bank to be less risky than a private one. It is strongly significant in the case of pooled OLS estimations and also when controlling for contract fixed effects. These results suggest a certain tendency to consider public agents more reliable for certain types of contracts, but less reliable than private firms for others. Instead, the income variable $(L G D P)$ turns out to be significant with the expected sign only in the case of contract fixed effects. ${ }^{23}$ It seems that the level of income of the host country matters just for a selected number of projects in which local firms are likely to run some commercial activities addressed to the local population. According to our working hypothesis, the EBRD credit granting strategy to local entrepreneurs is expected to be subject to

\footnotetext{
${ }^{23}$ The coeffcient is negative even in the case of firm fixed effects, but this is a marginal result being that the firm fixed effects model preferred less than the pooled OLS one.
} 
the condition that the degree of market economy (in the host country) needs to achieve at least a minimum lower bound to be effective. Instead, the coefficients of the variables describing the economic environment ( $L G O V, L F O R E X$ and $L S B_{-} P$ ) are not statistically significant at all, whereas the coefficient of the democracy variable is negative and statistically significant only in the case of controlling for contract fixed effects or clustering residuals by contracts (Table 12). ${ }^{24}$ This result tends to confirm the official claim that the EBRD promotes democratic institutions in transition countries regardless of the position of a country in the transition process. The time dimension does not always seem to be relevant in a number of our specifications; again, this could embed the general idea of the EBRD's mission to foster transition from a long-run perspective (Table 11).

[Table 11 about here]

[Table 12 about here]

To sum up, for local firms the fixed effects by type of contract turn out to be a good measure for identifying certain elements of the financing strategy of the bank over time. Each contract signed by the bank is granted according to the individual characteristics of the client. Having established this result, we now turn to the second subsample, composed of multinational firms, to assess the possible differences in the determinants of credit granting as compared with the first subsample.

\subsubsection{Multinational firms}

In our full sample, the total amount of credit granted to projects with an MNE as the unique borrower is relatively small. However, despite this limitation, we can focus on this specific group of firms to draw a first set of conclusions about the potential importance of favoring the entry of MNEs in transition countries as a pillar for supporting the creation of a market economy. Referring to the descriptive statistics in Table 8, we easily detect that the average amount of credit granted to an MNE, the size of the total investment, and the financing share are lower for MNEs than for local firms. This may reflect the fact that MNEs can apply for credits in international markets or pay for part of their investment in cash (as argued by Burstain, 2009, and García-Santana, 2012). The results of our econometric estimations are presented in Tables 13 and 14. The outcomes are quite robust and consistent across the different specifications.

The picture that emerges from these estimations is clearly distinguishable from the one associated with local firms. First, the income of the host markets is never significant: the

\footnotetext{
${ }^{24}$ Again, the positive sign in correspondence to the firm fixed effects should be read as not fully realiable result because of the F-test.
} 
MNE investments and detached from the income level of the destination markets, meaning that their investments target something more beyond obtaining a higher market potential for their business. Furthermore, the size of the credit granted to MNEs always has a quite negative (and statistically significant) association with the level of democracy and market openness. Once more, MNEs truly seem to be an anchor for the transition process. The EBRD seems to endorse their entry into quite close but not fully fledged democratic countries. Finally, as usual, the size of the credit $(L I P)$ is positively related to the value of the project and the condition of being a foreign public enterprise $(P U B L I C)^{25}$ two positive factors that determine the size of the credit.

According to our working hypothesis, this result confirms that the EBRD credit strategy privileges the MNE investment to foster the transition process to a market economy. Controlling for contract fixed effects does change the estimation results, but these effects turn out to be important (their $\rho$ is around 0.86) and help to shrink the standard errors. Our findings suggest that MNE investment projects were principally financed only on the basis of their quality, sector of destination, and the proper bank-tailored contracts to meet the needs of MNEs.

If our results were true, however, we cannot disregard that time matters: one would expect a clear association between the contract granted to the MNE and the time it was signed. In order to truly support the market creation process, the entry of MNEs should be favored at the beginning of the transition process. Our final set of estimations focuses exactly on this issue: establishing the extent to which the size of the granted credit turned to be a device to push the entry of MNEs in transition economies preferably at the beginning of the transition.

Table 15 displays our last set of estimations focusing on (3). First, our results are consistent and robust irrespective of the different estimation strategies we adopt. The most salient (and expected) outcome is the negative and always quite statistically significant coefficient of the covariate $L D E M_{j t} * M N E_{i}$. According to our working hypothesis, this result confirms that the entry of MNEs was privileged by the bank at the beginning of the transition period when host countries were building a democratic system. The interpretation of this result is strongly supported by the negative and again, always quite statistically significant coefficient of the covariate embedding the status of the privatization process $\left(L S B_{-} P\right)$. As soon as the privatization process started improving, the size of the EBRD credits started reducing. Finally, the relative singular position of MNEs in this credit granting process is also documented by the type of contract that they were likely to enjoy. As also shown in Table 15, the negative and statistically significant coefficient of the interaction term $d_{l o a n}{ }_{i t j s} * M N E_{i}$ reveals that the credits granted to MNEs were transferred through forms other than the canonical loan contracts usually

\footnotetext{
${ }^{25}$ This is the case of public foreign enterprises managing the development of projects in the field of natural monopolies, energy, or transport services.
} 
exploited for financing activities in risky markets (OECD, 2013). Once more, MNEs enjoyed a reputation effect that allowed for obtaining less binding credit contracts.

[Table 13 about here]

[Table 14 about here]

[Table 15 about here]

\section{Conclusions and discussion}

The dataset exploited in this study allows us to focus on the strategy adopted by the EBRD in granting credit with respect to the type of applicant. The EBRD was in a situation of monopoly in many transition countries, and the purpose of the activity was to support the transition to a market economy. The EBRD's shareholders are sovereign and assigned to the bank its mission to foster and not crowd out financial flows toward the private sector in these countries. According to our results, the entry of MNEs in transition countries aimed at being a pillar for consolidating the transition to a market economy. MNEs were expected to help foster the creation of a market economy. Some of our results confirm this hypothesis.

Let us focus on the elasticity between the credit size and the variation of the democracy index: for local firms, the credit size it is almost inelastic (its magnitude is around $0.45 \%$ ), whereas it is extremely elastic in the case of MNE credits (around 2.45\%). In the same vein, the MNE credit size turns out to be more elastic with respect to the value of the investment project (around $0.86 \%$ ) when compared with the case of local firms, with an elasticity settling between $0.70 \%$ and $0.80 \%$. In the bank's expectations, investments carried out by local firms are likely to be successful in an economic environment once the path toward a market economy is established. The sensitivity to the income level (namely GDP) is proof: credit granted to MNEs is completely inelastic against income variations in host countries, whereas credit granted to local firms is a bit more sensitive, with an elasticity of about $0.08 \%$.

The need to cope with high credit risk unambiguously forces the bank to adopt measures of protection using a client-screening scheme. As discussed in the economic literature, there is no unique scheme available to be implemented. In our sample, a screening device as general as the type of contract turned out to be an efficient tool. In line with the findings of Besley et al. (2010), however, our assessment offers elements to evaluate the need for potential changes to the EBRD's credit policy in the future. Since its creation, the EBRD's priorities have been encapsulated in the transition impact. At the early stage of the transition, the selection criteria for granting credit were relatively clear: the priority was evident (creation of the market economy), but 
nowadays other concerns such as social and economic cohesion or occupational safety should be taken into consideration.

Could the EBRD experience be transposed and adopted as a feasible strategy in other situations? It is undeniable that the proper selection of the projects is useful for driving the economic development as well as attracting the most efficient investors. The strategy implemented by the EBRD, however, cannot be considered a true benchmark strategy, since it relies on this specific feature: the EBRD operated as a monopolist in financing investments in transition countries at the beginning of the transition process. It was able to fine-tune foreign entry with respect to the evolution of the local economic environment as well. It is not so evident that replicating these types of market conditions will guarantee the attainment of the development objectives.

Nevertheless, more discussion could be generated if we were to investigate further results and insights by completing the statistical information at hand. First, we could refine the structure of the proposed exercise by improving the measurement of certain variables, such as investment returns or the economic environment in host markets. Following this path would enable us to provide a quantitative and reliable assessment of the effectiveness of the financed projects. Second, by controlling for the success of the financed projects, it would be possible to provide more insight into the possible association between the optimality of the credit-screening process and the effective impact of financed investments on host market economies. This second order of results would be extremely important in fixing reliable discriminatory criteria to provide a quantitative benchmark for selecting the proper projects in accordance with the development stages. By gathering information about the individual returns of the financed investments, we could obtain more precise data about the impact of the EBRD's financing policies. In particular, it could be possible to plan an exercise to discuss to the extent to which the EBRD's intervention has been effective in the long run and, eventually, the way it has been able to be a catalyst for mobilizing private investment financing after 2003.

Acknowledgement 1 We are grateful to M. Falk, J.L. Raymond, E. Turkisch, R. Wagner, the participants at the 11th IIOC Conference, and the scholars that read previous versions of this study for their comments and suggestions. Any remaining errors are our own responsibility. Financial support from research grants 2009SGR00600 and XRAPP is gratefully acknowledged.

\section{References}

[1] Baltagi, B. (2008): "Econometric Analysis of Panel Data", Wiley \& Son, 4th edition, Chichester. 
[2] Baum, Ch. (2006): “An introduction to Modern Econometrics using Stata", STATA Press, College Station.

[3] Besley, T, Dewatripont, M and Guriev, S. (2010): "Transition and transition impact", Report for the EBRD's Office of the Chief Economist.

[4] Bevan, A., Estrin, S. (2004): "The determinants of foreign direct investment into European transition economies", Journal of Comparative Economics, vol. 32, pp. 775-787.

[5] Boot, A. W. A, Thakor, A.V., Udell, G.F.(1991):"Secured Lending and Default Risk: Equilibrium Analysis, Policy Implications and Empirical Results", Economic Journal, vol 101(406), pp. 458-472.

[6] Burstein, A., Monge-Naranjo, A. (2009): "Foreign Know-How, Firm Control and Income in Developing countries" Quarterly Journal of Economics, vol.124(1), pp. 149-195.

[7] Damijab, J.P., Rojec, M., Majcen, B. and Knell, M. (2013): "Impact of firm heterogeneity on direct spillover effects of FDI: Micro-evidence from ten transition countries" Journal of Comparative Economics, vol. 41, pp. 895-922.

[8] Dang, Anh Duc (2013): " How Foreign Direct Investment Promote Institutional Quality: Evidence from Vietnam", Journal of Comparative Economics, forthcoming.

[9] EBRD (1999): "Financing EBRD", EBRD Press, London.

[10] Fang, Y, Hasan, I and Marton, K. (2011): "Bank Efficiency in South-Eastern Europe", Economics of Transition, vol. 19(3), pp. 495-520.

[11] García-Santana, M. (2012): "Foreign Ownership, Financial Frictions and the Size Distribution of Plants" CEMFI Discussion Papers.

[12] Holmström, B. (1999): "Incentive problems: A Dynamics Perspective", The Review of Economics Studies, vol.66 (1), pp. 169 -182.

[13] Inderst, R., Mueller, H.M. (2006):"Informed Lending and Security Design",Journal of Finance, vol. LXI (5), pp. 2137-2162.

[14] Lanine, G., Vander Vennet, R. (2007): "Microeconomic determinants of acquisitions of Eastern European banks by Wester European banks", Economics of Transition, vol. 15(2), pp. 285-308.

[15] Markusen, J. (2002): "Multinational firms and the theory of international trade", The MIT Press. 
[16] McGrattan, E., Prescott, E. (2007): "Openess Technology Capital and Development", Federal Reserve Bank of Minneapolis, Research Department Staff Report, 396.

[17] OECD (2013) " Perspective on Global Development 2013. Industrial Policies in a Changing World",Paris.

[18] Polity IV project (2007), www.cidcm.umd.edu/polity/.

[19] Roland, G. (2000): "Transition and Economics: Politics, Markets and Firms" MIT Press.

[20] Stiglitz, J., Weiss, A.(1981):"Credit Rationing in Markets with Imperfect Information",American Economic Review, vol. 71(3), pp. 393-410.

[21] Vuylsteke, Ch. (1995): "The EBRD: its mandate, instruments, challenges and responses", MOCT-MOST: Economic Policy in Transitional Economics, vol. 5(2), pp. 129-155.

[22] Wooldridge, J. (2006):" Introductory Econometrics. A Modern Approach", 3rd edition, Thomson South-Western. 


\section{LIST OF TABLES}

Table 1: EBRD contracts and their frequency (1991-2003)

(Source: EBRD, Calculus: authors)

\begin{tabular}{|l|l|l|}
\hline Contract & Freq. & $\mathbf{\%}$ \\
\hline Debt & 1 & 0.06 \\
\hline Equity & 141 & 7.92 \\
\hline Guarantee & 100 & 5.62 \\
\hline Line of Credit & 7 & 0.39 \\
\hline Loan & 949 & 53.31 \\
\hline Loan/Line of credit & 1 & 0.06 \\
\hline Loan/Shares & 96 & 5.39 \\
\hline Loan/Guarantee & 1 & 0.06 \\
\hline Senior debt & 72 & 4.04 \\
\hline Shares & 404 & 22.70 \\
\hline Shares/Loan & 2 & 0.11 \\
\hline Shares/Loan/Share & 1 & 0.06 \\
\hline Share/Loan/Guarantee & 1 & 0.06 \\
\hline Subordinated debt & 4 & 0.22 \\
\hline TOTAL & $\mathbf{1 7 8 0}$ & $\mathbf{1 0 0}$ \\
\hline
\end{tabular}

Table 2: Descriptive statistics on loans (value $€$ mill. )

(Source: EBRD, Calculus: authors)

\begin{tabular}{|llllllll|}
\hline & Variable & Obs & Mean & Std. Dev & Median & Min & Max \\
\hline Total sample $^{1}$ & & & & & & & \\
& Bank financing & 945 & 21.25 & 27.76 & 12.7 & 0.1 & 233.76 \\
& Tot. project value & 936 & 60.81 & 109.94 & 29.25 & 0.1 & 923.9 \\
\hline Up to 1995 & & & & & & \\
& Bank financing & 219 & 19.98 & 23.53 & 10.90 & 0.2 & 142 \\
& Tot. project value & 220 & 68.24 & 115.81 & 31.85 & 0.5 & 923.9 \\
\hline From 2000 onwards & & & & & & & \\
& & & & & & & \\
& Bank financing & 438 & 21.19 & 31.36 & 10.00 & 0.1 & 233.76 \\
& Tot. project value & 427 & 50.60 & 94.94 & 15.00 & 0.1 & 750 \\
\hline
\end{tabular}

\footnotetext{
${ }^{1}$ The difference between the number of observation in bank financing and total project value is due to lack of data for one of the two variables.
} 
Table 3: Descriptive statistics on shares (value $€$ mill.)

(Source: EBRD, Calculus: authors)

\begin{tabular}{|llllllll|}
\hline & Variable & Obs & Mean & Std. Dev & Median & Min & Max \\
\hline Total sample & & & & & & & \\
& Bank financing & 402 & 9.05 & 13.93 & 3.2 & 0.1 & 125 \\
& Tot. project value & 402 & 34.57 & 76.98 & 8.2 & 0.1 & 1028.9 \\
\hline Up to 1995 & & & & & & \\
& Bank financing & 84 & 10.14 & 11.82 & 5.9 & 0.1 & 53.4 \\
& Tot. project value & 84 & 35.92 & 59.96 & 18.6 & 0.7 & 384.1 \\
\hline From 2000 onwards & & & & & & & \\
& Bank financing & 100 & 7.45 & 11.95 & 3.1 & 0.3 & 53.7 \\
& Tot. project value & 99 & 26.87 & 63.57 & 4.8 & 0.5 & 365.8 \\
\hline
\end{tabular}

Table 4: Descriptive statistics: Cumulated investment by region (\%)

(Source: EBRD, Calculus: authors)

\begin{tabular}{lrrr}
\hline Regions & $\mathbf{1 9 9 1 - 1 9 9 5}$ & $\mathbf{1 9 9 6 - 1 9 9 9}$ & $\mathbf{2 0 0 0 - 2 0 0 3}$ \\
\hline & & & \\
Russia & 19.9 & 29.1 & 28.8 \\
Central Europe and Baltic States & 45.9 & 32.9 & 36.0 \\
\hline Eastern Europe and the Caucasus & 11.8 & 11.9 & 7.5 \\
South-Eastern Europe & 16.8 & 13.5 & 20.5 \\
\hline Central Asia & 5.6 & 12.6 & 7.2 \\
\hline
\end{tabular}

Table 5: Descriptive statistics: Cumulated investment by sector (\%)

(Source: EBRD, Calculus: authors)

\begin{tabular}{lrrr}
\hline Sector & $\mathbf{1 9 9 1 - 1 9 9 5}$ & $\mathbf{1 9 9 6 - 1 9 9 9}$ & $\mathbf{2 0 0 0 - 2 0 0 3}$ \\
\hline & & & \\
Finance & 19.6 & 27.0 & 30.2 \\
Environment &.. & 4.1 &.. \\
\hline Food & 2.6 & 8.1 & 9.0 \\
Telecom & 14.5 & 6.8 & 4.9 \\
Energy & 9.5 & 9.7 & 8.9 \\
\hline Oil/Gas/Nat.Res. & 10.8 & 10.3 & 8.4 \\
Transport & 8.8 & 3.4 & 16.1 \\
Others & 34.3 & 30.6 & 22.4 \\
\hline
\end{tabular}


Table 6: Descriptive statistics: Cumulated investment by sector and group of firms (1991-2003) (\%) (Source: EBRD, Calculus: authors)

\begin{tabular}{lrr}
\hline Sector & MNE & \multicolumn{2}{c}{ Local firms } \\
\hline Bank & 11.8 & 11.0 \\
Finance & 38.5 & 35.6 \\
Food & 20.7 & 6.6 \\
Manufacturing & 6.5 & 5.2 \\
& & \\
\hline
\end{tabular}

BOX 1: LIST OF VARIABLES

\begin{tabular}{|l|l|}
\hline LDEM & Logarithm Index of democratic level in the country hosting the investment (Polity IV) \\
\hline LFOREX & Logarithm of the EBRD indicator on trade liberalization and foreign exchange rate \\
\hline LGDP & Gross domestic product per-capita of the host country (IMF statistics) \\
\hline LGOV & Logarithm of the EBRD indicator on governance and entreprise restructuring \\
\hline LIP & Logarithm Total value of the investment project \\
\hline LIV & Logarithm Value of the investment financed by the EBRD \\
\hline LSB_P & Logarithm of the EBRD indicator on small and large scale privatization \\
\hline MNE & Dummy for Multinational firm \\
\hline PUBLIC & Dummy variable for presence of a public client or other interests of the bank in the project \\
\hline Sector & Dummy by sector \\
\hline Year & Time dummy \\
\hline
\end{tabular}

Table 7: Correlation statistics

\begin{tabular}{|l|l|l|l|l|}
\hline & LDEM & LGOV & LFOREX & LSB_P \\
\hline LDEM & 1 & & & \\
\hline LGOV & $0.385^{* * *}$ & 1 & & \\
\hline LFOREX & $0.207^{* * *}$ & $0.588^{* * *}$ & 1 & \\
\hline LSB_P & $-0.107^{* * *}$ & $0.381^{* * *}$ & $0.414^{* * *}$ & 1 \\
\hline
\end{tabular}

$* * * 1 \%$ significance level; 
Table 8: Descriptive statistics

\begin{tabular}{|c|c|c|c|c|c|c|}
\hline & Variable & Obs & Mean & Std. Dev & Min & Max \\
\hline \multicolumn{7}{|c|}{ Sample } \\
\hline & GDP per-capita $(\$)$ & 1706 & 2706.5 & 2143.6 & 151.48 & 13937.4 \\
\hline & Polity IV index (DEM) & 1662 & 6.5 & 2.85 & 0 & 10 \\
\hline & EBRD Credit Value ( $€$ mill. ) & 1766 & 16.5 & 24.2 & 0 & 233.7 \\
\hline & Total project value (€ mill. ) & 1750 & 49.23 & 97.87 & 0 & 1028.9 \\
\hline & Financing share & 1728 & 0.6 & 0.33 & 0.009 & 1 \\
\hline \multicolumn{7}{|l|}{1993} \\
\hline & GDP per-capita $(\$)$ & 68 & 2167 & 1519.7 & 225.8 & 6801.8 \\
\hline & Polity IV index (DEM) & 68 & 7.32 & 2.45 & 0 & 10 \\
\hline & EBRD Credit Value (€ mill.) & 71 & 20.36 & 23.9 & 0.1 & 100.12 \\
\hline & Total project value (€ mill.) & 71 & 69.98 & 96.95 & 1.3 & 464.7 \\
\hline & Financing share & 71 & 0.43 & 0.28 & 0.04 & 1 \\
\hline \multicolumn{7}{|l|}{2003} \\
\hline & GDP per-capita $(\$)$ & 260 & 3292.8 & 2539.6 & 248.2 & 13937.4 \\
\hline & Polity IV index (DEM) & 254 & 6.61 & 3.04 & 0 & 10 \\
\hline & EBRD Credit Value (€ mill.) & 270 & 13.69 & 23.7 & 0.1 & 230.2 \\
\hline & Total project value(€ mill.) & 271 & 33.26 & 77.4 & 0.1 & 750 \\
\hline & Financing share & 270 & 0.69 & 0.34 & 0.01 & 1 \\
\hline \multicolumn{7}{|l|}{ MNE } \\
\hline & EBRD Credit Value (€ mill.) & 167 & 9.91 & 14.62 & 0.045 & 95.411 \\
\hline & Total project value( $€$ mill. $)$ & 158 & 26.31 & 41.73 & 0.045 & 255 \\
\hline & Financing share & 156 & 0.57 & 0.356 & 0.049 & 1 \\
\hline \multicolumn{7}{|l|}{ Local } \\
\hline & EBRD Credit Value (€ mill.) & 1599 & 17.18 & 24.84 & 0 & 233.76 \\
\hline & Total project value $(€$ mill. $)$ & 1592 & 51.51 & 101.5 & 0 & 1029 \\
\hline & Financing share & 1572 & 0.61 & 0.333 & 0.009 & 1 \\
\hline
\end{tabular}


Table 9: Econometric results: Full sample

Method of estimation: Pooled OLS, Value in brackets: Std Error,

Dependent variable: LIV

\begin{tabular}{|c|c|c|c|}
\hline & OLS & OLS & OLS \\
\hline $\mathrm{C}$ & $0.51(1.07)$ & $-0.62(0.3)^{*}$ & $0.51(1.06)$ \\
\hline LIP & $0.82(0.01)^{* * *}$ & $0.82(0.03)^{* * *}$ & $0.82(0.01)^{* * *}$ \\
\hline PUBLIC & $0.26(0.07)^{* * *}$ & $0.26(0.05)^{* * *}$ & $0.26(0.07)^{* * *}$ \\
\hline LDEM & $-0.98(0.61)$ & $-0.53(0.21)^{* *}$ & $-0.98(0.61)$ \\
\hline LGDP & $0.06(0.03)^{*}$ & $0.06(0.05)$ & $0.06(0.03)^{*}$ \\
\hline LGOV & $-0.21(0.11)^{*}$ & $-0.21(0.1)^{*}$ & $-0.21(0.11)^{*}$ \\
\hline LFOREX & $-0.16(0.1)$ & $-0.14(0.13)$ & $-0.16(0.1)$ \\
\hline LSB_P & $-0.08(0.10)$ & $-0.09(0.05)^{*}$ & $-0.09(0.10)$ \\
\hline Dummy years & yes & yes & yes \\
\hline Dummy sectors & yes & yes & yes \\
\hline LDEM*years & yes & yes & yes \\
\hline \multicolumn{4}{|l|}{ Tests: } \\
\hline D. Years $=0$ & 0.81 & $802.11^{* * *}$ & 0.80 \\
\hline D. Sectors $=0$ & $4.61^{* * *}$ & $5889 * * *$ & $4.49 * * *$ \\
\hline $\mathrm{LDEM}^{*}$ year $=0$ & $1.91^{* *}$ & $4.3 \mathrm{e}^{05^{* * *}}$ & $1.90 * *$ \\
\hline $\mathrm{LDEM}^{*}$ year $=$ D. Years & $1.71^{*}$ & $2628^{* * *}$ & $1.73^{*}$ \\
\hline Robustness errors & Heterosk. & Cluster & Clusters \\
\hline & & (contracts) & (firm) \\
\hline Adj. R-Square & 0.84 & 0.84 & \\
\hline OBS & 1348 & 1342 & 1614 \\
\hline
\end{tabular}

*** $1 \%$ significance level; ${ }^{* *} 5 \% ; * 10 \%$ 
Table 10

Econometric results: full sample

Method of estimation: Fixed effects, Value in brackets: Std Error,

Dependent variable: LIV

\begin{tabular}{|c|c|c|c|c|}
\hline & Fixed effects & Fixed effects & Fixed effects & Fixed effects \\
\hline $\mathbf{C}$ & $-0.96(0.54)^{*}$ & $4.77(6.68)$ & $0.57(0.26)^{* *}$ & $4.77(3.1)$ \\
\hline LIP & $0.79(0.01)^{* * *}$ & $0.73(0.1)^{* * *}$ & $0.79(0.02)^{* * *}$ & $0.73(0.00)^{* * *}$ \\
\hline PUBLIC & $0.19(0.07)^{* * *}$ & $-0.49(0.6)$ & $0.19(0.01)^{* * *}$ & $-0.49(0.31)$ \\
\hline LDEM & $-0.47(0.29)$ & $3.73(2.06)^{*}$ & $-1.13(0.17)^{* * *}$ & $3.74(1.2)^{* * *}$ \\
\hline LGDP & $0.09(0.03)^{* * *}$ & $-0.75(0.68)$ & $0.09(0.05)$ & $-0.74(0.35)^{* *}$ \\
\hline LGOV & $-0.15(0.11)$ & $0.18(0.78)$ & $-0.15(0.08)^{*}$ & $0.18(0.46)$ \\
\hline LFOREX & $-0.19(0.09)^{* *}$ & $-0.15(0.58)$ & $-0.19(0.12)$ & $-0.15(0.39)$ \\
\hline LSB_P & $-0.83(0.09)$ & $-0.39(0.95)$ & $-0.08(0.06)$ & $-0.39(0.62)$ \\
\hline Dummy years & yes & yes & yes & yes \\
\hline Dummy sectors & yes & yes & yes & yes \\
\hline LDEM*years & yes & yes & yes & yes \\
\hline Fixed effects & Contract & Firm & Contract & Firm \\
\hline \multicolumn{5}{|l|}{ Tests: } \\
\hline F-test: fixed vs pooled & $9.30^{* * *}$ & 0.83 & & \\
\hline$\sigma_{u}$ & 0.39 & 1.17 & 0.39 & 1.16 \\
\hline$\rho$ & 0.29 & 0.74 & 0.61 & 0.74 \\
\hline Robustness errors & White & White & Cluster & Cluster \\
\hline R-Square (within) & 0.82 & 0.68 & $\begin{array}{c}\text { (contract) } \\
0.89\end{array}$ & $\begin{array}{c}(\text { firm }) \\
0.68\end{array}$ \\
\hline OBS & 1342 & 1348 & 1342 & 1348 \\
\hline Groups & 13 & & 13 & \\
\hline
\end{tabular}

*** $1 \%$ significance level; ${ }^{* *} 5 \% ; * 10 \%$ 
Table 11

Econometric results: Local firms

Method of estimation: OLS, Value in brackets: Std Error,

Dependent variable: LIV

\begin{tabular}{|c|c|c|c|}
\hline & OLS & OLS & OLS \\
\hline C & $0.42(1.13)$ & $0.4(0.2)$ & $0.42(1.13)$ \\
\hline LIP & $0.81(0.01)^{* * *}$ & $0.81(0.02)^{* * *}$ & $0.81(0.01)^{* * *}$ \\
\hline PUBLIC & $0.22(0.07)^{* * *}$ & $0.22(0.04)^{* * *}$ & $0.22(0.07)^{* * *}$ \\
\hline LDEM & $-0.46(0.58)$ & $-0.90(0.17)^{* * *}$ & $-0.46(0.58)$ \\
\hline LGDP & $0.05(0.03)$ & $0.05(0.04)$ & $0.05(0.04)$ \\
\hline LGOV & $-0.23(0.12)^{*}$ & $-0.24(0.1)^{* *}$ & $-0.23(0.12)^{*}$ \\
\hline LFOREX & $-0.1(0.1)$ & $-0.08(0.16)$ & $-0.1(0.1)$ \\
\hline LSB_P & $-0.06(0.11)$ & $-0.07(0.05)^{*}$ & $-0.06(0.11)$ \\
\hline Dummy years & yes & yes & yes \\
\hline Dummy sectors & yes & yes & yes \\
\hline LDEM*years & yes & yes & yes \\
\hline \multicolumn{4}{|l|}{ Tests: } \\
\hline D. Years $=0$ & 0.61 & $1581^{* * *}$ & $4.37^{* * *}$ \\
\hline D. Sectors $=0$ & $4.55^{* * *}$ & $4615^{* * *}$ & $1.59^{*}$ \\
\hline $\mathrm{LDEM}^{*}$ year $=0$ & $1.59^{*}$ & $91354^{* * *}$ & 1.50 \\
\hline LDEM*year $=$ D. Years & 1.50 & $3.3 \mathrm{e}^{05 * * *}$ & 0.61 \\
\hline \multirow[t]{2}{*}{ Robustness errors } & Heterosk. & Cluster & Clusters \\
\hline & & (contract) & (firm) \\
\hline Adj. R-Square & 0.84 & 0.84 & 0.84 \\
\hline OBS & 1231 & 1226 & 1231 \\
\hline
\end{tabular}

*** $1 \%$ significance level; ${ }^{* *} 5 \% ; * 10 \%$. 
Table 12

Econometric results: Local firms

Method of estimation: Fixed effects, Value in brackets: Std Error,

Dependent variable: LIV

\begin{tabular}{|c|c|c|c|c|}
\hline & Fixed effects & Fixed effects & Fixed effects & Fixed effects \\
\hline $\mathbf{C}$ & $-0.95(0.55)^{*}$ & $0.86(13.42)$ & $0.95(0.20)^{* * *}$ & $-2.89(3.8)$ \\
\hline LIP & $0.78(0.01)^{* * *}$ & $0.70(0.1)^{* * *}$ & $0.78(0.02)^{* * *}$ & $0.69(0.11)^{* * *}$ \\
\hline PUBLIC & $0.14(0.07)^{* *}$ & $-0.51(0.6)$ & $0.15(0.02)^{* * *}$ & $-0.51(0.33)$ \\
\hline LDEM & $-0.45(0.29)$ & $0.1(2.44)$ & $-0.45(0.13)^{* * *}$ & $1.4(0.31)^{* * *}$ \\
\hline LGDP & $0.08(0.03)^{* *}$ & $-0.83(0.69)$ & $0.08(0.04)^{*}$ & $-0.83(0.33)^{* *}$ \\
\hline LGOV & $-0.15(0.11)$ & $-0.08(0.83)$ & $-0.15(0.09)$ & $-0.08(0.49)$ \\
\hline LFOREX & $-0.13(0.09)$ & $0.06(0.62)$ & $-0.13(0.16)$ & $0.06(0.42)$ \\
\hline LSB_P & $-0.07(0.10)$ & $-0.15(1.06)$ & $-0.07(0.09)$ & $-0.14(0.72)$ \\
\hline Dummy years & yes & yes & yes & yes \\
\hline Dummy sectors & yes & yes & yes & yes \\
\hline LDEM*years & yes & yes & yes & yes \\
\hline Fixed effects & Contract & Firm & Contract & Firm \\
\hline \multicolumn{5}{|l|}{ Tests: } \\
\hline F-test: fixed vs pooled & $8.36^{* * *}$ & 0.80 & & \\
\hline$\sigma_{u}$ & 0.40 & 1.5 & 0.40 & 1.71 \\
\hline$\rho$ & 0.31 & 0.83 & 0.60 & 0.86 \\
\hline Robustness errors & White & White & Cluster & Cluster \\
\hline & & & (contract) & (firm) \\
\hline R-Square (within) & 0.82 & 0.68 & 0.88 & 0.68 \\
\hline OBS & 1226 & 1231 & 1226 & 1231 \\
\hline Groups & 13 & & 13 & \\
\hline
\end{tabular}

*** $1 \%$ significance level; ${ }^{* *} 5 \% ; * 10 \%$. 
Table 13

Econometric results: Multinational firms

Method of estimation: OLS, Value in brackets: Std Error,

Dependent variable: LIV

\begin{tabular}{|c|c|c|c|}
\hline & OLS & OLS & OLS \\
\hline C & $4.03(2.83)$ & $17.8(5.7)^{* *}$ & $4.02(2.83)$ \\
\hline LIP & $0.86(0.05)^{* * *}$ & $0.86(0.08)^{* * *}$ & $0.86(0.05)^{* * *}$ \\
\hline PUBLIC & $0.27(0.16)^{*}$ & $0.27(0.40)$ & $0.27(0.16)^{*}$ \\
\hline LDEM & $-2.43(1.37)^{*}$ & $-2.43(0.87)^{* *}$ & $-2.43(1.37)^{*}$ \\
\hline LGDP & $0.04(0.17)$ & $0.04(0.11)$ & $0.04(0.16)$ \\
\hline LGOV & $0.21(0.50)$ & $0.21(0.3)$ & $0.21(0.49)$ \\
\hline LFOREX & $-0.75(0.4)^{* *}$ & $-0.75(0.27)^{* *}$ & $-0.75(0.37)^{* *}$ \\
\hline LSB_P & $-0.12(0.30)$ & $-0.11(0.31)$ & $-0.11(0.30)$ \\
\hline Dummy years & yes & yes & yes \\
\hline Dummy sectors & yes & yes & yes \\
\hline LDEM*years & yes & yes & yes \\
\hline \multicolumn{4}{|l|}{ Tests: } \\
\hline D. Years $=0$ & $2.65^{* * *}$ & $70.30 * * *$ & $2.39 * *$ \\
\hline D. Sectors $=0$ & $8.74^{* * *}$ & $46078^{* * *}$ & $8.72^{* * *}$ \\
\hline $\mathrm{LDEM}^{*}$ year $=0$ & $2.54^{* * *}$ & $42.01^{* * *}$ & $2.40^{* *}$ \\
\hline LDEM*year=D. Years & $2.52^{* * *}$ & $70.06^{* * *}$ & $2.39^{* *}$ \\
\hline \multirow[t]{2}{*}{ Robustness errors } & Heterosk. & Cluster & Clusters \\
\hline & & (contract) & (firm) \\
\hline Adj. R-Square & 0.88 & 0.88 & 0.88 \\
\hline OBS & 117 & 116 & 117 \\
\hline
\end{tabular}

$1 \%$ significance level; $* * 5 \% ; * 10 \%$ 
Table 14

Econometric results: Multinational firms ${ }^{a}$

Method of estimation: Fixed effects, Value in brackets: Std Error,

Dependent variable: LIV

\begin{tabular}{|c|c|c|}
\hline & Fixed effects & Fixed effects \\
\hline C & $12.92(9.42)$ & $12.92(6.5)^{*}$ \\
\hline LIP & $0.85(0.06)^{* * *}$ & $0.86(0.09)^{* * *}$ \\
\hline PUBLIC & $0.95(0.7)$ & $0.95(0.25)^{* * *}$ \\
\hline LDEM & $-4.74(4.31)$ & $-4.74(1.40)^{* *}$ \\
\hline LGDP & $0.03(0.15)$ & $0.03(0.1)$ \\
\hline LGOV & $0.18(0.5)$ & $0.18(0.50)$ \\
\hline LFOREX & $-0.7(0.46)$ & $-0.70(0.22)^{* *}$ \\
\hline LSB_P & $-0.21(0.32)$ & $-0.21(0.30)$ \\
\hline Dummy years & yes & yes \\
\hline Dummy sectors & yes & yes \\
\hline LDEM*years & yes & yes \\
\hline Fixed effects & Contract & Contract \\
\hline \multicolumn{3}{|l|}{ Tests: } \\
\hline F-test: fixed vs pooled & $2.98^{* * *}$ & \\
\hline$\sigma_{u}$ & 1.47 & 1.46 \\
\hline$\rho$ & 0.86 & 0.86 \\
\hline Robustness errors & White & Cluster \\
\hline R-Square (within) & 0.87 & $\begin{array}{c}\text { (contract) } \\
0.88\end{array}$ \\
\hline OBS & 116 & 116 \\
\hline Groups & 8 & 8 \\
\hline
\end{tabular}

*** $1 \%$ significance level; ${ }^{* *} 5 \% ;^{*} 10 \% ;^{a}$ Firm-fixed effects estimations cannot be run for lack of sufficient observations. 
Table 15

Econometric results: Testing the support to development

Method of estimation: Fixed effects, Value in brackets: Std Error,

Dependent variable: LIV

\begin{tabular}{|c|c|c|c|c|c|c|c|}
\hline & OLS & OLS & OLS & Fixed effects & Fixed effects & Fixed effects & Fixed effects \\
\hline $\mathrm{C}$ & $1.90(2.72)$ & $1.9(2.71)$ & $1.87(0.52)^{* * *}$ & $-0.03(5.2)$ & $2.10(2.4)$ & $-0.03(3.29)$ & $2.10(0.58)^{* * *}$ \\
\hline LDEM & $-0.14(1.19)$ & $-0.14(1.18)$ & $-0.15(0.27)$ & $7.07(2.68)^{* *}$ & $0.52(1.15)$ & $7.07(1.83)^{* * *}$ & $0.52(0.18)^{* *}$ \\
\hline MNE & $0.94(0.71)$ & $0.94(0.72)$ & $0.98(0.63)$ & $14.87(7.07)^{* *}$ & $0.96(0.8)$ & $14.87(4.2)^{* * *}$ & $0.96(0.56)$ \\
\hline LDMNE & $-0.58(0.33)^{*}$ & $-0.58(0.34)^{*}$ & $-0.57(0.26)^{*}$ & $-6.31(3.21)^{*}$ & $-0.54(0.39)$ & $-6.31(1.7) * * *$ & $-0.53(0.23)^{* *}$ \\
\hline d_Loan & $0.81(0.09)^{* * *}$ & $0.81(0.09)^{* * *}$ & $0.82(0.13)^{* * *}$ & $0.56(0.35)$ & (dropped) & $0.55(0.23)^{* *}$ & (dropped) \\
\hline d_LMNE & $-0.49(0.26)$ & $-0.05(0.27)$ & $-0.09(0.16)$ & $-3.6(1.2)^{* * *}$ & $-0.19(0.24)$ & $-3.59(0.72)^{* * *}$ & $-0.19(0.14)$ \\
\hline LGOV & $0.24(0.18)$ & $0.24(0.18)$ & $0.23(0.16)$ & $0.09(1.01)$ & $0.28(0.20)$ & $0.09(0.90)$ & $0.28(0.19)$ \\
\hline LFLOREX & $0.14(0.21)$ & $0.14(0.22)$ & $0.19(0.58)$ & $0.06(0.75)$ & $0.17(0.18)$ & $0.05(0.85)$ & $0.17(0.58)$ \\
\hline $\mathrm{LSB}_{-} \mathrm{P}$ & $-1.01(0.19)^{* * *}$ & $-1.01(0.19)^{* * *}$ & $-1.03(0.46)^{* *}$ & $-0.83(1.28)$ & $-0.98(0.19)^{* * *}$ & $-0.83(1.2)$ & $-0.98(.048)^{*}$ \\
\hline Dummy years & yes & yes & yes & yes & yes & yes & yes \\
\hline Dummy sectors & yes & yes & yes & yes & yes & yes & yes \\
\hline LDEM*years & yes & yes & yes & yes & yes & yes & yes \\
\hline Fixed effects & & & & Firm & Contract & Firm & Contract \\
\hline$\sigma_{u}$ & & & & 2.67 & 0.89 & 2.67 & 0.89 \\
\hline$\rho$ & & & & 0.89 & 0.33 & 0.89 & 0.33 \\
\hline Robustness errors & Whire & Cluster & Cluster & White & White & Cluster & Cluster \\
\hline & & (Firm) & (Contract) & & & (Firm) & (Contract) \\
\hline R-Square (within) & 0.35 & 0.35 & 0.35 & 0.41 & 0.24 & 0.41 & 0.24 \\
\hline OBS & 1366 & 1366 & 1366 & 1366 & 1359 & 1366 & 1359 \\
\hline
\end{tabular}




\section{A Appendix: List of sectors}

The following table shows all the sectors that firms asking for a finance belong to:

Banking, Finance and holding

Chemical (including Pharmaceutical)

Education

Electronic and Hi-Tech

Energy

Environment

Food and beverage (incl. agriculture)

Health and personal care

Hotels and tourism

Infrastructure (transport)
Local services (water, waste...)

Media

Manufacturing

Metal

Natural resources

Oil and gas

Real estate

Telecommunication

Trade and retail

Vehicles 